NBER WORKING PAPERS SERIES

LABOR MARKET SEGMENTATION, WAGE DISPERSION AND UNEMPLOYMENT

Kevin Larg

William T. Dickens

Working Paper No. 4073

NATTONAL BUREAU OF ECONOMIC RESEARCH

1050 Massachuse:ts Avenue

Cambridge, MA 02138

May 1992

This paper was supported in part by a Sloan Faculty Research Fellowship (Lang) and the Institute of Industrial Relations, Berkeley (Dickens). We are grateful to Gustavo Gonzaga for excellent research assistance and to Olivier Blanchard, Lawrence Katz, Douglas Orr, Janes Rebitzer, Robert Rosenthal, Andrew Weiss and participants in seminars at Berkeley, Boston University, MoGill and the NBER for helpful comments and discussion. 'This paper is part of NBER's research program in Labor Studies. Any opinions expressed are those of the authors and not those of the National Bureau of Economic Research. 
NBER Working Paper \#4073

May 1992

\title{
LABOR MARKET SEGMENTATION, WAGE DISPERSION AND UNEMPLOYMENT
}

\begin{abstract}
This paper briefly reviews the empirical evidence on labor market segmentation and presents some new results on the similarity of the pattem of segmentation across 66 different countries. The paper goes on to consider how unemployment might be understood in a labor market segmentation framework.

Existing models of unemployment in a dual labor market suggest that unemployment should be concentrated among those who are ultimately employed in high wage jobs. In fact, unemployment seems to be concentrated among workers who are more likely to be found in low wage jobs. This happens even though at least some workers find low wage jobs easy to obtain. We develop a segmented labor market model capable of explaining these facts and then explore its implications for the aggregate unemployment rate. We find that it fits well with the facts.
\end{abstract}

Kevin Lang

Department of Economics

Boston University

270 Bay State Road

Boston, MA 02215

and NBER
William T. Dickens

Department of Economics

University of Califomia

Betkeley, CA 94720

and NBER 
Labor market segmentation is not as naturally part of a discussion of unemployment as it may at first seem. On the one hand, in some of its versions, labox market segmentation is nuch broadex than a theory of unemployment. It is a research program with an agenda that differs markedly from that pursued by most economists. On the other hand, In 1 ts more narrow form, it is theory of wage determination and of the allocation of workers to jobs with different wages, and not a theory of unemployment.

As a consequence, we begin by developing a model of labor market segmentation and exploxing les consequences for unemployment. The model is slmultaneously concerned with the mictoeconomic aspects of unemployment - who is unemployed -, and with the macroeconomic aspects - what determines the aggregate level of unemployment. We find that unemployment w1ll be more prevalent among low skill workers who also end up disproportionately in lowwage jobs. At the macroeconomic level, unemployment will be positively correlated with the average wage and the fraction of low productivity workers. In terms of observable variables, unemployment is, under certain circumstances, positively corralated with the average wage and the fraction of workers in the low-wage sector.

In our previous work, we have stressed that labor narket segmentation models share two key elements. The first is a theory of wage determination where wages for simflar workers differ anong sectors of the economy. Early advocates of labor market segmentation models argued that the labor market could be usefully descrlbed as consisting of a small number of segments with different patterns of wage determinacion. However, more recent wark which is more closely linked with malnstream traditions has placed more emphas is on the differences in wages across segments than on the frugality of the segmentation approach. 
In addition to a theory of wage determination, every model of labor market segmentation requires a theory of how workers are allocated to sectors. It is here that labor market segmentation theory departs most sharply from mainstream economiss. Jobs in high-wage sectors are not allocated by strict price rationing, Some people who are qualified for and who desire jobs in the high-wage sectors are unable to get them.

These two elements are not sufficient to generate unemployment. It is posslble for high and low-wage sectors to coexist without any unemployment ensuing. Workers who were unable to get high-wage jobs might simply accept employment in low-wage sectors. Indeed many development econonists believe that labor market segmentation is an important aspect of labor narkets in developing countries even though open unemployment may be very law. Those excluded from the modern sector find employment in the informal sector.

This is not to say that discussions of unemploynent are absent from the litereture on labor market segmentation. On the concrary, some of the early work on labor market segmentation was motivated by the desire to exphin high rates of unemploymene among young blacks. Thus al though labor mazket segmentation theories were interested in unemployment, the emphasis was on who 1s unemployed rather than on the level of unemploynent. One of our objectives Is to foralize the insights from this tradition.

Piore (1975, formalized by Rebitzer and Taylor, 1991) argues that labor garket segrentation is a response to flux and uncertainty. The primary (highwage) sector is organized so ss to shelter workers and firms fron that uncertainty. The brunt of the flux is felt in the secondary (Iow-wage) sector where jobs are frequently shorc-term. In good times, therefote, unemployment conststs primarily of what neoclassical economists would call frictional unemployment among workers in the secondary sector although there may be an 
absolute shortage of jobs in the secondary sector in bad times. Workers in the secondary sector may experience frequent spells of unemployment interrupted by relatively short-term employment in low-wage jobs.

Wial (1991) finds that, at least for young white working class males, low-wage jobs appear to be readily available. Vacancy rates in these jobs are high. The short duration of employment may reflect the low value placed on holding such jobs as well as the demand fluctuations emphasized by Plore. High-wage jobs are much more difficult to obtaln and being hired by a highwage employer appears to be largely a matter of luck.

To sumarize the insights from this literature - unempioyment is concentrated among the types of workers who are disproportionacely represented in the low-wage sector. Ironically, this finding fs readily accomodated by market-clearing models of unemployment. Horkers whose wages are low are likely to have a value of leisure near there wage. Fluctuations in their value of leisure will cause them to move 1 and out of the labor force. Unemployment arises if nonemployment spells are misclassifled as unemployment or if laboz force reentry is assoclated with short-terin unemployant.

However, the relation between potential earrings and.unemployment is not as eastly explained wichin the context of models in which matkets do not clear. Therefore, one of the ohjectives of chis papar is to develop a formal model with this implication. Having developed such a model, we then ask whether it is capable of explaining empirical regularities with regard to the aggregate unemplayment rate. Our findings are quite supporive of the model.

Obviously, the relevance of these models depends on the importance of labor market segmentation. Consequently, our flrst step is to establish the inportance of sectoral vage differentials. To a large degree this has been accomplished in previous wark (Dickens and Kacz, 1987acb; Katz and Summers, 
1990). We review this work only briefly. Instead, we concentrate on the incernational evidence. We find strong evidence of a widely-shared pattern of interindustry wage differentials.

We then develop our theoretical model in steps. In sectlon II, we develop e simple bilateral search model with homogenepus firms and warkers, This section is intended to make it clear how segmentation can be generated in the model and to show how cechnical detall can be handied so that discussion of technical detall can be dispensed with in later section. Section III considers the case of heterogeneous firms and bomogeneous workers. Although ehis represents a nacural step along the way to our model with heterogeneous workers, the secrion serves primarily to clarify some issues regarding the desirability of activist policy in the presence of labor market segmentacion. We suggest that this case is much weaker than some authors have previously claimed. Section IV considers the case of heterogeneous workers and shows that for some paramecer values low-productivity workers w11 have higher unemployment rates than mora productive workers. Moreover wage differencials will often exceed differences in productive potential. In section $V$, we show thac owners of capital are made better off anc all workers worse off if employers make arbitrary distinctions among workers, Section vI develops the macfoeconomic implications of the model and compares them with empirical findirgs.

\section{The International Fervasiveness of the Induscry Wage Structure}

There is a large and growing literature on interindustry wage differencials. The resurgence of this literature (Dickens and Katz, 1987asb; Krueger and Summers, 1987, 1988; Katz and Sumers, 1990) began 1n the United States, but has beet widely replicated since then. The universal finding is 
that there are large wage differentials across indugtries within a country. Where it is possible to conduct such tests, the wage differencials cannot be accounted for by measurable indfvidual characteristics or by working conditions. It, of course, remains possible that the wage differentials are accounted for by unmeasured worker or job charactertstics, but we argue elsewhere (Dickens and Lang, 1992) that this is unlikely.

Industry is only imperfectly correlated with labor market segment. -Most industries have a mix of types of workers. Autombile assembly may be carried out almost exclustvely by workers in the high-wage sector, but manufacture of some components may involve workers in the low-wage sector. Janitorial and security personnel may be high paid and integrated into the firm's incernal market or may be low paid contract workers. Nevertheless, since industries which pay high wages tend to pay high wages to workers in all occupations, Induscry is likely to be at least a reasonable proxy for sector of employment.

Our first cask is tharafore to determine the extent to which it is posstble to talk about a single "industry wage structure." Previous research has suggegted that the wage scructure is quite simflar in countries such as the United Kingdor and the Sovlet Union with very different economies (Krueger and Summers, 1987; Dickens and Katz, 1987). However, other countries show much lower rates of correlation. Is this because there are a few different patterns around which countries cluster or because countries differ in the extent to which they conform to a common pattern? In the latter case, it will be easier to consider the effect of labor market segmencation on unemploynenc. To answer this question we collected data on wages paid in 32 one and two digit industries in 66 countries for the year 1985 . He conducted a paximum likelihood factor analysis of these data. We could easily reject the hypothesis of no common factors (Chi-square statistic of 1.116 with 97 degrees 
of freedom, $p<.0001$ ) A single factor explains 47 of the standardized variance in the rages for these countries. Th1s is remarkable when one considers that a high fraction of the variance -- particularly in developing countries $-1 s$ Frobably measurement error due to different definitions of the 1ndustries and different composition of the relatively highly aggregated industries in different countries. The single factor is rearly perfectly correlated with the vector of everage wages in each industry across countrieg. Only thirteen of the 66 countrles have loadings less than .5 on the factor. Most of these are LDCs. We have begun to search for correlates of the loadings and $1 t$ appears that they are positively correlated with reai GDP per capita and investment as a fraction of GDP.

We could also reject the hypothesis of only one common factor with a high degree of confldence (Chi-square statistic of 436 with 96 degrees of freedor). However the second factor explains only $12 \mathrm{t}$ of the standardized variance in out wage data set. The firse factor of the two factor model continues to have all che properties of the factor from the single factor model. The second factor shows no obvious pactern either for the industry values or for the countries which load on it. None of the variables we have explored are correlated with it. Table 1 presents the values of the standardized orthogonal factors for the 32 1ndustrles. Table 2 contains the loadings for all countries for both factors. These results suggest that we can talk about a common pattern of labor market segmentation to which countries conform to dffering degrees.

\section{The Dasic Model}

The basic model, which is extended in later sections, draws on the model sketched in Lang (1991) and formalized in Montgomery (1991). It is 
essentlally a large economy version of the model developed in the latter paper.

There are $N$ identical workers and bN 1dentical firms where $\mathrm{N}$ is assumed to be large, Initially, we do not formally model the determination of $b$. Later we will assume free entry untll the point that expected profits are zero but w1ll not otherwise madel the firm's entry declslon. Each firm has exactly one fob availeble. Firms announce the wages they will pay to any worker they hire and cannot credibly promise to hire excess workers even where this is an optmal stracegy... Workers each apply to a single fira. If a firm tecefves only one applicacion, it hires that worker. If it recelves more than one applfcation, it chooses randomly among the applicants.

We denote firm i's profits by

(1) $\pi_{1}-F_{1}\left(v-w_{1}\right)-d$

where $F$ is the probability that the firm fills its vacancy, $v$ is the value of the worker's output, $w$ is the wage and $d$ is the cost of looking for a worker.

Claim: The following 1s a sub-game perfect equilibrium. All workers apply randomly to firms with the probabilicles assigned to each firm identical for all workers. A worker's probability of applying to firm 1 satisfies the following conditions:
(2) $\mathrm{EM}_{1} \mathrm{w}_{\mathbf{i}}=\mathrm{K}$
$w_{1}>K$

where EM is the probability of getting a job and apply to the firm with probability equal to zero if $w \leq K$.

All firms offer a wage equal to

(3) $w=-K(\ln k-\ln v) /(1-k / v)$. 
Before passing to a proof of this clatm, it 1 s important to be clear that although (2) can be interpreted as an equi:ibrium condition, at this stage it Is a statement about strategles. Given that all workers use the same mixed strategies, equation (2) telis us the probability of applying to each firm given any combination of wage offers by the firms.

Proof: It is obvious that given the strategies of the other workers, no worker can make himself better off by choosing a different strategy. Equation (2) ensures that the worker gets the same expected wage wherever he applies except for firms which pay less than $K$ and where he would be worse off if he appliec.

To show that the optimal wage for firms to set is given by equation (3), we derive expressions for $F$ and $E M$, the filled job and employment rates.

Let $q$ be the probability that each worker applies to a given firm. Then the probability that a worker who applies to that firm will be employed is

(4) $E M=\left(1-(1-q)^{N}\right) / N \square$.

let $z=$ Ne, the expected number of applicants to the firm. Then as $\mathrm{N}$ gets large, 1

(5) $E M=z^{-1}\left(1-e^{-z}\right)$.

where $z$ is the expected number of applicants at the firm.

The probability that a flrm fills its position is given by

This is just the Foisson approximation to the binomial distribution. 
(6) $F=1-(1-q)^{N}$

which cends to

(7) $F-1-e^{-z}$

as $N$ gets large.

Substituting for $F$ and $w$ In equation (1) yields

(B) $\pi_{\mathrm{I}}=\left(1-\mathrm{e}^{-z}\right) \mathrm{v}-\mathrm{Kz}-\mathrm{d}$.

Maximizing with respect to $z$ gives

(9) $x / y-e^{-z}=0$

Solving for $z$ and substicuting for $z$ in (5) and then for EM in (2) gives equation (3). The value of $\mathrm{k}$ can be derived from the zero ptofit condition (assuming free entry ensures zero profits), and is unlque, but has no closedform solution and is of no intrinsic incerest.

It is easily verifled that $w$ is increasing in $v$ (holding $K$ flxed) so that if firms differ with respect to $v$, those with higher values of output will pay higher wages. These results parallel those derfved by Montgonery (1991). Nevertheless, when employment is endogenous, it must be 1nterpreted with caution. One response of flrms with more productve workers will be to hire more workers, thereby lowering their marginal product. Our point here is only to derive the basic behavior of vorkers faced with wage differences across firas and to point out that such differentials can be endogenous within our framework.

We have concentrated on this equilibrium, because we find it the nost plausfble. We expect that there are equilibria in which both vorkers and 
flrms play mixet strategies but none 1 in which all workers play pure strategies. An equilibrium in which firms, at lesst, play pure strategies seems preferable.

\section{IFI. Two-Sectors/Hamogeneous Workers}

The standard Harris-Todaro model and its more zecent efficiency wage varlancs (Bulow and sumers, 1986) assume that workers sre homogeneous and thac there are two sectors which either pay different wages for exogenous reasons or for reasons related to technology. Typically the low-wage sector is assumed to be a marker-clearing sector. Unemployment occurs among individuals trying to obtain employment in the high-wage sector. There are some small differences becween the implications of the Harris-Todaro models in which jobs are allecated by lottery and the Bulow-Sumers model in which individuals essentially wait in line for a high-wage job. We will return to these differences shorty.

To show the relation between our model and the standard models, we begin by considering the case of two sectors with exogenously determined wages. All firms within a sector are identical. All wotkers are identical. In the equilibrium in which all workers have the same strategies, workers randomize where they apply with equal probability of applying to each firm within a sector, but apply with greater probability to any single firm in the high-wage sector than to any single firm in the low-wage sector. Thus unemployment rates are higher anong workers who apply to high-wage firms, and vacancy rates are lower in that sector.

So far, The rodel is a minor variation on the harris-Todaro model. There is, in effact, a lottery for jobs in toth sectors. However, even in this form, the model has implications which depart from previous models. In the 
standard Harris-Todaro model increasing employnent in the high-wage sector increases the desirability of queuing for employnent in the high-wage sector and therefore increases unemplayment. Equilibriun is achieved by expanding queving in the high-wage sector until unemployment in that sector equals what It would have been in the absence of the employment expansion. In the HarrisTodaro model, while the unemployment rate in each sector (by assumption zero in the low-wage seccor) Is unchanged, the shift of applfcations towards the high-wage and high unemployment increases the unemployment rate. Essentially the same argument applies to the Bulow/Sumers waiting-time model.

It is worth noting in models of this type that shifting one worker fron applying to the low-wege sector to applying to the high-wage sector has only a second-order effect on output. In essence this arises because the expected wage and hence the expected output (net of unemployment) is the same in the two sectors in equilfbrium. Drckens and Lang (1988) argue that if a worker could be costiessly shifted from employment in the low-wage sector co employment in the high-wage sector, this would be desirable since firms would be no worse off given that the marginal profit on a worker is zero and the worker would be strictly better off. In the standard queie uremployment models, the case of costless transfer makes litcle sense. AlI the benefits from expanding employment in the high-wage sector will be dissipated by Increased unemployment in that sector, ${ }^{2}$

${ }^{2}$ Bulow and sumers claim that in the waiting time model there are beneftcs to expanding employment in the high-wage sector. The difference between their analysis and ours is that we compare equitibrta while they include the benefits that arise out of the transition. Workers who are walting for high-wage employment are made strlctly better off by en expansion of the high-wage sector, and thus receive a one-time benefit. Given the reality that we start from a distortionary tax base so that the costs of financing the expansion of employment are finite and that the benefles are of strictly 11mited duration, this one time benefit from expanding high-wage employment provides a very weak basis for advocating industrial and other activist policles. 
Because there is unemployment in both sectors in our model, it is posslble that expanding employment in one sector will reduce the unemployment zate in both sectors and bring down the aggregate unenployment rate. To see under what circumstances this is possible, we begin by elaborating our model slightiy.

lee $p$ be the probability that a worker applies to a high-wage firm and I$p$ the probabilicy that he applies to a low-wage fira. Let $\alpha$ be the fraction of firms which encer the high-wage sector and 1-a the fraction that enter the low-wage seccor. Then
(10) $q_{h}=p /(\alpha\llcorner N)$
$q_{1}=(1-p) /((1-\alpha) b N)$

The employment and filled job rates for each of the sectors are:

(11) $\mathrm{EM}_{\mathrm{h}}=\alpha \mathrm{b}\left(1-\mathrm{e}^{-p /(\alpha b)}\right) / \mathrm{p}, \quad \mathrm{EM}_{1}=(1-\alpha) b\left(1-\mathrm{e}^{-(1-\mathrm{p}) /((1-\alpha) b)}\right) /(1-\mathrm{p})$

(12) $F_{h}=1-e^{-F /(\alpha b)}, \quad F_{1}=1-e^{-(1-p) /((1-\alpha) b)}$.

Labor market equilibrium, of course, requires that expected earnings be equal in the two sectors.

To complete the model we need to model entry into the two sectors. This will turn out to be the essential part of the model whtch deternines whether subsidizing high-wage or low-wage employment is desirable. We begin by assuming that thare is a fixed entry cost ia the low-wage sector but that entry costs rise as the number of entrants in the high-wage sector increases. We assume that output prices in the two sectors are fixed. This is equivalent to assuming that there is a unique equilibrium filled job rate in the low-wage sector. In the bigh-wage sector, we assume that the structure of entry casts 
1s such that the filled job rate which firms require in order to enter the sector is given by

(13) $F_{h}-\gamma_{1}+\gamma_{2} a b$.

Note that together with che labor market equilibrium condition, (11) and (12) imply that

(14) $\ln \left(1-F_{h}\right) / F_{h}-\left(w_{h} / w_{1}\right)$ ln $\left(1-F_{1}\right) / F_{1}$.

Suppose now that government adopts a balanced-budget tax policy in which 1t subsidizes entry into or employment in the high-wage sector and taxes it in the low-wage sector. Then the filled-job rate firms require to enter the lowwage sector will rise. By equation (14) the filled-job rate must also rise in the high wage sector. Since the unemployment rate is positively related to the filled-job rate, the unemployment rate also rises in both sectors. We have already seen that when the unemployment rate within each sector is unaffected by the Inereased high-wage employment, the effect on aggregate output is zero. ${ }^{3}$ In this case since the unemployment rate in both sectors rises, the output effect is negative.

What happens is that the decline in employment opportunities in the lowwage sector shifts workers into the high-wage sector to a greater extent than the subsidy creates employment opportunities. Thus not only do we shift workers from the low unempioyment to the high unemployment sector, but we increase the unemployment within each sector, thereby increasing overall unemployment.

${ }^{3}$ It is easy to see that if unemployment frcteases in boch sectors, average output falls. The output of the average person is $\mathrm{pEM}_{\mathrm{h}} \mathrm{Wh}_{\mathrm{h}}+\mathrm{Cl}_{1-}$ p) $E M_{1} w_{1}$. Since equilibrium requires $\mathrm{EM}_{\mathrm{h}} \mathrm{w}_{\mathrm{h}}=\mathrm{EM}_{1} \mathrm{w}_{1}$, changes in the proportion of workers applyling to each sector have no effect on output. However, a higher unemployment rate means a lower $E M_{h}$ and $E M_{1}$. So average output decline, 
It should be evident that had we reversed our assumptions about the relation between the number of firms entering the sector and the cost of entering so that the cost was unaffected by entzy in the high-wage sector and equation (13) applied in the low-wage sector, unemployment within each sector would have decreased and welfaxe increased as a result of the tax/subsidy program. The effect on aggregate unemployment is ambiguous since the policy continues to shift workers to the high-unemployment sector.

In general it is elear that the welfare effects will depend on the elasticity of entry with respect to the tax/subsidy. Without strong priors about how this elasticiey varies among sectors, we can make no strong statements about the desirability or lack thereof of subsidizing high-wage employment. Also, other modifications of the nodel such as worker beterogeneity in eversion to unemployment can lead to different results. Our results should nevertheless sound a note of caution regarcing the desirability of polictes designed to "capture warker rents."

\section{TV. Hetęrogeneous Workers}

The two-sector model with homageneous workers is largely uninformative regarding who will be unemployed. The evidence (clark and summers, 1979) suggests that much of job search ends with employment in "bad" jobs (shorttern jobs) when it does not end in labor force whthdrawal. 4 The homogeneous worker model in which employment is concentrated among those seektng high-wage employment is not consistent with the descriptive literature on segmented labor markets. There the emphasis was on the unemployment of disadvantaged workers "confined" to the low-wage sector. To investigate this question, we

${ }^{4}$ Some would say that the evidence suggests that job-seekers are disproportionately bad workers. This distinction is not inportant. for our argument. 
need to develop the model for the case where workers are heterogeneous. As vill be seen, the resules of the model are substantially modified by this change.

To model this formally, we assume that there are two types of workers. both with productivity $v$. The number of workers of each type $\left(\mathrm{N}_{1}\right.$ and $\left.\mathrm{N}_{2}\right)$ is assumed to be large. Firms pay an entrance fee of d if they wish to advertise for worker. They can hire only one worker. Firms announce the wage they w1Il pay if they hire a worker. They can observe worker type but cannot. condition the wage on the type. Workers observe the wage and apply to a single firm. If more than one worker applies to the firm, the firm chooses randomly among the type 1 workers, and, if there are no type 1 applicants, among the type 2 workers. Thus firms have lexicographical preferences. Equivalently, it is a partial tie-breaking rule. They maximize profits, but for equal profits, they prefer type 1 warkers. This is similar to the situation which would arise if there were an infinitesigal procuctivity difference between the two types, but simplifies the mathematics. Blanchard and Diamond (1990) assume a similar lexicographical preference for workers with shorter unemployment durations, However, because theit wage-setting assuntions are quite different, they reach concluslons which differ significantly fromi ours.

We again consider only the case where all workers of a given type have identical strategies. As in the homogeneous worker models, these strategies are probabilities of applying to firms. Let $z_{1}$ and $z_{2}$ be che expected number of applicants of type 1 and type 2 at the firm. Glven the large number of workers and firms, each firm acts as if its behavior does not affect the behavior of other firms. Similarly workers cisregard the effect of their behavior on ocher workers. 
Under these clzcumstances, flrms maximize their profits which are given

by

$$
\pi=\left(1-e^{-\left(z_{1}+z_{2}\right)}\right)(v-w)-d
$$

subject to

$$
\left(1-e^{-z_{1}}\right) w / z_{1} \leq k_{1}
$$

and

$$
\mathrm{e}^{-z_{1}}\left(1-\mathrm{e}^{-z^{2}}\right) w / z_{2} \leq k_{2}
$$

and

$$
z_{1} \geq 0, z_{2} \geq 0
$$

where $k_{1}$ and $k_{2}$ are the expected wages for type 1 and type 2 workers if they apply to other firms, Equation (18) is the condition that type 1 workers will apply until their expected wage in the firm is the same as elsewhere.

Equation (19) is the equivalent expresston for type 2 workers. The additional term reflects the fact that firms will always hire type 1 workers in preference to type 2 warkers. Although they are also equilibrium conditions, equations (18) and (19) summarize the strategies of type 1 and type 2 workers in a maner analogous to equation (2).

Gla1m: There is a stb-game perfect equilibrium with symetric strategies by all workers of a given type in which some firms offer the optimal wage for the case where there are only type 1 workers and others offer a wage equal to $k_{1}$. only type 1 workers apply to the hlgh-wage firms, and only type 2 workers apply to low-wage firms. The ratio of type 2 workers to low-wage firms is given by

$$
z_{2}=-\log \left(1-d /\left(v-k_{1}\right)\right)
$$


The ratio of type 1 workers to high-wage firms is given by (9).

Proof: We first show that if firms follow the strategies stated above, the workers' strategles constitute an equilibrium of the sub-game. If a type 1 . worker deviates and applies to a low-wage job, he receives $k_{1}$ with certainty which is equal to his expected wage if he applies to a high-wage job. There Is thus no incentlye to deviate. A type 2 worker's expected wage is

$$
k_{1}\left(1-e^{-z_{2}}\right) / z_{2}-k_{1} d /\left[\left(v-k_{1}\right)\left(\log \left(1-d /\left(v-k_{1}\right)\right)\right]\right.
$$

where we have used (21) to derive the right-hand-side of the equality.

A type 2 worker who deviates receives

$$
e^{-z_{1}} w_{1}=-k_{1}^{2} \log \left(k_{1} / v\right) /\left(v-k_{1}\right)
$$

where we have used (3) and (9).

To see that (22) exceeds (23), note that if (23) were greater than (22), we would have

$$
\log \left(1-d /\left(v-k_{1}\right)\right) k_{1} \log \left(k_{1} / v\right)>d
$$

But the left-hand-side of (24) is less than

$$
d\left(k_{1} /\left(v-k_{1}\right)\right) \log \left(v / k_{1}\right)-d \log \left(v / k_{1}\right) /\left(\left(v / k_{1}-1\right)\right)<d .
$$

So deviation will not be optfmal for type 2 workers.

He now show that it will not be optimal for firms to deviate from their equilbrius strategies. Both high-wage and low-wage firms make zero expected profit. From section 2, it is obvious that it will not be profitable to offer any other wage which attracts only typel or onky type 2 workers. Therefore we 
need only show that any wage whlch attracts both types of workers 15 not profitable.

Suppose the wage was set so that $z_{1}$ and $z_{2}$ were both positive. Denote the expected number of applicants by $x_{1}$ and $x_{2}$. We show that $x_{1}+x_{2}<z_{2}$ so that the offer cannot be proftcable. Since equations (18) and (19) hold with equality

$$
\left(1-e^{-z_{2}}\right)\left(1-e^{-x_{1}}\right) /\left(z_{2} x_{1}\right)-e^{-x_{1}}\left(1-e^{-x_{2}}\right) / x_{2} .
$$

The left-hand-side of $(26)$ is declining in $z_{2}$. Therefore a sufficient condition for the offer to be proficable is

$$
\left(1-e^{-\left(x_{1}+x_{2}\right)}\right)\left(1-e^{-x_{1}}\right) /\left(x_{1}\left(x_{1}+x_{2}\right)\right)>e^{-x_{1}}\left(1-e^{-x_{2}}\right) / x_{2} .
$$

Rearranging terms gives

$$
\left(1-e^{-x_{2}}\right) / x_{2}<e^{x_{1}}\left\langle 1-e^{-\left(x_{1}+x_{2}\right)}\right)\left(1-e^{-x_{1}}\right) /\left(x_{1}\left(x_{1}+x_{2}\right)\right)=R .
$$

At $x_{1}-0,(28)$ holds with equality. The remainder of this part of the proof is a tedtous exercise in showing that the derivative of the right-hand-side with respect to $x_{1}>0$.

Taklig derivatives gives

(29) $d R / d x_{1}-\left(\left(1-e^{-\left(x_{1}+x_{2}\right)}\right) /\left(x_{1}\left(x_{1}+x_{2}\right)\right)\left(\left(1-e^{-x_{1}}\right)\left(2 e^{x_{1}}-e^{x_{1}} / x_{1}-e^{x_{1}} /\left(x_{1}+x_{2}\right)\right)+1\right)\right.$.

This will be positlve iff the term in square brackets is positive. To determine whether this is positive, note that it is increasing in $x_{2}$; we need therefore only verify that

$$
2 e^{x_{1}}\left(x_{1}-1\right)\left(1-e^{-x_{1}} 1\right) / x_{1}+1>0 .
$$


The left hand side (excluding the +1 ) is most negative when $x_{1}-0$ in which case expression (30) holds with equality. For posttive $x_{1}$, the lrequality bolds. Therefore inequality (28) holds, and the alternative offer will not be profitable.

It is surprlsing that large wage differentials can result from small productivity differentials when wages are determined endogenously. The reason is that even if there is only an infinitesimel difference in productivity, firms w11 always'prefer the higher productivicy worker if they cannot offer then different wages. High-wage firms will attract large numbers of type 1 workers. Consequently, type 2 workers who apply there will have a low probability of getting a job. To atcract type 2 workers, firms would like to comnlt to hiring them rather than type 1 workezs if both types of workers apply. In the absence of such camitments, firms cas set a wage that does not attrect type 1 workers. Thus an equllibrium arises in which type 1 workers apply to high-wage firns and type 2 workers apply to Iow-wage firms.

Thus in this example both wages and employment races are higher for the type 1 workers. It is worth noting that from cross-section data on wages and employment alone, the model is indistinguishable from a standard buman capital model with heterogeneous jobs and workers. In a standard hedonic model, wages could be regressed on some measure of worker type such as education, and we would observe a positive return to education. If no measuzes of worker type were available, we could regress wages on measures of job type. The return to job type would be interpreted as a compensating differential or as a proxy for unobserved worker skill.

Aside from the finite wage differential between the two types of workers, the equilibriun has the interesting feature that vacancy rates are high in 
low-wage firms and that the unemployment tate for type 1 workers is higher. Consequently, this model goes only part way cowards generating the zype of segmentation described in Labor market segmentation literacure. Equally productive workers have different wages, and those confined to the low-wage sector are worse off. Vacancles are higher in the low-wage sector than in the high-wage sector. However, in contrast with the literature, the model suggests lawer not highar unemplayment rates for the disadvantaged group. ${ }^{5}$

This last result can be reversed if we are wllling to drop the assumption that the two groups are only infinitesimally different in productivity. When type 2 workers are less productive than type 1 workers, equilibria may exist where both types apply to high-wage jobs and only type 2 workers apply to lowwage jobs or where only type 1 workers apply to high-wage jobs and both spply to low-wage jobs. ${ }^{6}$ In this case it is easy to generate examples in which the equilibrium corresponds to the descriptive Iiteracure. We present wo such examples.

First, suppose that type 1 workers produce 2 and type 2 workers produce 1.65. The cost to firms of enterlng the market is 94 . Then the high-vage sector pays .62. Only type 1's apply. They have an employment rate of .5.

Shen wages are exogenous, it is easfly shown that the concentration of unemployment among applicants to high-wage jobs can be reversed when workers are heterogeneous. Consider the following example. There are two high-wage jobs and three low-wage jobs. Similarly there are two type 1 and three type 2 workers. High-wage jobs pay 2 while low-wage jobs pay 1 . It is readily verlfied than the following is an equilibrium - both type 1 workers apply to the high-wage jobs and all three low-wage workers appiy to the low-wage jobs. The employment ate for high-wage applicants is .75 which is higher than the $19 / 27(.70)$ employment rate for lowwage applicants.

${ }^{6}$ Obviously there are some parameter values for which the separating equtlibrium will be the unique sub-game perfect equllibrium. There are also parameter values for which there is a unique wage, but these can only arise if type 1 workers and type 2 workers are present in just the right ratio for che given value of $d$. We conjecture that there are no sub-game perfect equilibria in which both types apply to both types of jobs. 
The low-wage sector pays .49. Type 1 workers have an employment rate in this sector of .84 while type 2 workers have an employment rate of .46 . Obviously. type 2 workers have a higher overall unemployment rate than do type 1 workers. Moreover, at least to type 1 workers, low-wage jobs seem plentifui. This is reflected in the different vacancy rates -28 in the low-wage sector and $20 \%$

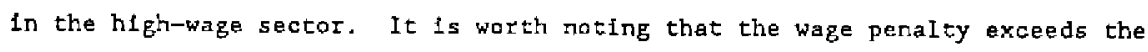
productivity difference. Type 1 workers ere less than 25 more productive but their expected wage is almost twice that of type 2 workers. ${ }^{7}$

In our second example, type 2 workers apply to both types of jobs. Type 1 workers continue to have productivicy equal to 2 but type 2 workers have productivity equal to 1.60 . The parameter d is set equal to 1.19 . In this case there is an equildbrium in which high-wage firms pay .5. Type 1 workers heve an employment rate of .82 while type 2 workers have an employment rate of .22 in this sector. The wage in the low-wage sector is .32 and the employment rate is .35 for type 2 workers. Thus relative to the bigh-wage sector, fobs seem plentiful for type 2 workers although, reflecting low vacancy rates (.07 in the low-wage sector and ,04 in the high-wage sector). they are not plentiful in an absolute sense. Again both the wage differential between the two sectors and the expected wage differential between the two types of workers are large relative to the productivity differentlal.

\section{Gapitalist Exploitation:Splitting the Working Ciass}

One of the recurring themes in Marxist labor economics is that capitalfsts use various devices to create false distinctions and thus disunity among workers (Bowles, 1985; Roemer, 1979). By generating a hierarchy within

\footnotetext{
7 The average wage received by type 1 workers cannot be calculated without assumptions about the relative number of the two types of warkers.
} 
the ranks of the working class, capitalists prevent workers from recognizing their common interests. In addition, if the "favored" workers recognize that they are being explotted, they may nevertheless be reluctant to challenge employers or the distinctions aut of fear of losing their favored status. One such distinction discussed in the Marxist licerature is race (Reich, 1981).

The major difficulty with arguments of this type is that it is often difficult to demonstrate that the division helps capltalists or hurts workers. If firms "buy off" workers from organizing, it is probable that they are helping some workers and hurting others. The workers who are "bought off" must be better off than they expect to be if they resist capitalist exploitation. Thus upward-sloping wage profiles may be a mechanism for ensuring the cooperation of senior workers (Stone, 1975) and may be injurfous to the positions of wotkers as a class and Individual workers over their Iifetimes. However, senior workers presumably benefit from this policy. In partcular, in most models of discrimination, it is difficult to see how capitalists benefit from the discrimination except from the long run benefte of maincaining their position. Discrimination serves prifarily to transfer resources from blacks to whices, thereby buying white cooperation and forestalling worker unity.

In the model in the endogenous wage model of che previous section discrimination is advantageous to capitalists, as a class, in the short rum. By dividing previously homogeneous workers such as blacks and whites, capitaliscs hurt both types of workers in the short run while making themselves better off. Thus dividing the work force can be advantageous ever in the absence of a natural tendency towards worker unity in opposition to capicalists.

To see this suppose that blacks and whites are equally productive. In the absence of discriminarion, firms would choose randomly among black and 
white workers who would, in turn, have equal wages and employment probabilities. Now suppose that firms could collectively agrea to give biring preference to whites. We saw in the last section that in the long run, the equflibrium would 1nvolve blacks recelving lower wages and lower expected wages net of unemployment and would not affect the wages of whites. In the long run, free entry drives firms' profits co zero so that the discrimination haras blacks and helps nelther white workers nor capitailsts.

In the short Iun, however, before new firms can enter to take advantage of the lower wages paid to blacks, hiring black workers at the lower wage will be profitable. of course, in che shar: run equilfbriun the expected profit from hiring blacks at low wages and whites at hlgh wages must be the same. Thus hiring whites must be profitable which can only be achieved by lowerling their expected wage, The following theorem makes this argument more precise.

Theorem: If the number of eirms is fixed at the level determined by the nonciscriminacory equilibrium, flems make postrive profits in the discriminatory equilibrium. Workers who are given hiring preference recelve lower wages and have a lower employment rate than in the nondiscriainatory equilibritum, Workers who are disfavored in the hiring process, receive lawer wages but have a higher employment rate than In the nondiscriminatory equilibrium. Both types of workers have lower expected wages than in the nondiscriminatory equilibrium. Alcernatively, if the number of firms is fixed as the number present in the discriminatory equilibrium and firms cease to discriminace; firns earn negative profits

progf: Since profits in the two sectors must be equal, after agreeing to discrimlnate against blacks, firms will dfstribute thenselves so that the 
expected number of applicancs is higher in the high-wage sector than in the low-wage sector and thus higher than in the nondiscriminatory equilibrium in the high-wage sector and lower than in the low-wage sector than in the nondiscriminatory equilibrium. Since the expected nuber of applicants and the enployment rate are negaclvely related, 1 follows that the employwent race for favored workers will be lower and the employment rate for disfavored workers will be higher in the discriminatory equilibriur than in the nondiscriminatory equilibrium. Recall from section II that we can treac the expected number of applicants as a choice vartable for the firm. From equation (9) choosing a lower expected number of applicants is the discriminatory equilibrius than in the nandiscriminatory equilibritu is consistent with profit maximization by high wage firms only if the expected wage net of unemployment (K) for the favored workers is lower in the discriminatory equilibrium than in the nondiscriminatory equilibrium. From (3) $\mathrm{dw} / \mathrm{dK}>0$. Therefore the wage is also lower in the discriminatory equlibrium, Since the disfavored workers receive a tage equal to the expected wage of the favored workers, cheir wage and expected wage must be lower than in the nondiscriminatory equilibrium.

In the static model we have developed here, the discriminatory equilibrlum can only arise by the consclous collective action of che capitalists. However, it is obvious that in a more dynamic model this equilibrium can be supported by appropziate strategles regarding responses to out of equilibrium moves. In particular, a firm. would find it advantageous to comrit to hizing black workers in prefecence to white workers. However, if an the next nove all firms responded by not discriminating against blacks, the deviating firm would make an expected loss in future periods which might be suffictent to deter it from deviating. 
Thus capltalists can use arbitrary divisions among workers to increase thelr ow profits at the expense of all workers. It appears passible to generate this type of equflibrium without resorting to the sort of conspiracy which sone people would call cooperative equilibria.

\section{Segmented Labor Markets and the Unemployment Rate}

In this section we consider the implications of the segrented labor market model for the aggregate unemployment rate. We consider the case where there are a large nuber of different cities with free mobility of labor anong the cities. In this icase the expected wage for type 1 workers must be $k_{1}$ and the expected wage for type 2 workers must be $k_{2}$ in all clties. Wages and the size of the sectors may differ across the cities because of differences in the productivity of the different types of workers in the eftles and because of differing entry costs,

Let the ratio of type 1 workers in low-wage jobs to type one warkers in bigh-wage jobs be $a$, and the ratio of type 2 workers in low- and high-wage jabs to type 1 workers in high-wage jobs be $\beta$ and $\gamma$, respectively. ${ }^{8}$ Ther the unesployment rate in the city is given by

$$
\overline{E M}-\left(E M_{1 h}+\alpha E M_{11}+\beta E M_{2 h}+\gamma{ }^{F M} M_{21}\right) /(1+\alpha+\beta+\gamma)
$$

where $5 \mathrm{M}_{1 \mathrm{j}}$ is the employment rate of workers of type 1 in jobs of type $\mathrm{j}$.

The average wage among employed workers in the city is given by

$$
\bar{w}-\left(E M_{1 h} w_{h}+\alpha E M_{11} w_{1}+\beta E M_{2 h} w_{h}+\gamma E M_{21} w_{1}\right) /\left(E M_{1 h}+\alpha E M_{11}+\beta E M_{2 h}+\gamma E M_{21}\right)
$$

Substituting (32) into (31) glves

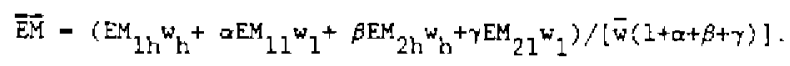

\footnotetext{
${ }^{8}$ In general either $\alpha$ or $\beta$ or both will be zero.
} 
Recaling that the expected wage is $k_{1}$ for type 1 workers and $k_{2}$ for type two workers regardless of the sector in which they are employed gives

$$
\overline{E M}-\left(k_{1}(1+\alpha)+k_{2}(\beta+\gamma)\right) /[\bar{w}(1+\alpha+\beta+\gamma)]
$$

Somewhat surprisingly, the employment (and therefore the unemployment) rate in the city depends only on the average wage in the city and on the fraction of workers who are type 1 . In the case of homogeneous workers, the average wage is a sufficient statistic for the unemployment race. We need informacion on neitter the relative wages 1 in the twa sectors nor their zelative size. It is worth noting that this result is quite general. We have not made use of the details of our model.

If It were possible to control far $\alpha$ and $\beta$, then conditional on these variables, unemployment and the size of the low-wage sector would be positively correlated. Of course, it is noc posable to control for a and $\beta$ bue these variables are related to worker heterogeneicy within sectors. Using the occuparional categories of Carnoy and Rumberger (1980), Orr (1991) has derived estimates of the size of the low and high-wage sectors and the degree of worker hecerogeneicy within sectors as well as the average wage in a crosssection of U.S. cities. He finds that the unemployment rate is positively correlated with both the average wage and the relative size of the secondary sector. ${ }^{9}$

\section{VII, Segmented Labor Markets and Unemploymenc: An Assessment}

9 Orr's paper was not developed with our model in mind. None of his varfatles corresponds perfectly to our theoretical conscructs, but his empirical work Iepresents the closest approxination we could flnd. We are grateful to him for providing us with additional speciflcations not avallable in his paper. 
There are two types of regularicles which a theory of unemploysent should account for, In the firgt place, we are interested in the microecononics of unemployment - who is unemployed and, In a more dynamic context, the pattern of hazard rafes for exic from unemployment. In eddition, we are concerned with the macroeconomics of unemployment - what accounts for intertemporal and international variation in the Level and duration of unesployment.

In our view the labor market segmentation approach provides a fruitful if underdeveloped approach to accounting for these regularities. The approach remains underdeveloped, because as yet there 1 s no agreed upon approach to segmentation. Economists who work within the labor market segmentation perspective share the view that wages do not adjust to clear the labor narket, but this shared perspective allows eansiderable freedom to approach modelling in different ways. Because of this potential for divergence, we suspect that some econorists will believe that we have not really addressed the labor market segmentation perspective. Instead, some will argue that we have developed a model of search unemployment while others wiIl argue that we have developed an efflclency wage model. Both coments would be true, but these approaches are not inconsistent with the labor market segmentation perspective.

What our formal modelling has brought out is the ability of such modelling to generate the relation between Iow wages and high unemployment which was emphasized in the early literature on segmented labor markets. In most models there is little reason to expect a relation between innate productivity and unemployment. Our model improves on these models since it can generate the desfred correlation, but tt must be recognized that the opposite correlation can also be generated at least for sufficiently snall productivity differences. 
In addition, many models predict that unemploywent duration and postemployment wages will be positively correlated. While our model is not dynamic and cannot therefore address chis question explicitly, the one-period model suggests a more complex relation. In our example where both type 1 and type 2 workers apply to the high wage section, but only type 2 workers apply to che low-wage sectors, the shortest durations would be among the type 1 workers applying to the high-wage sector while the longest durations would be among the type 2 workers applying to this sector.

A natural way to extend the model is to make it dynamic in a ranner analogous to Blanchard and Diamond (1990). If we assume that skills deterforate with unemployment, our model, like theirs, imp1ies negative duration dependence of unemployment. Moreover, higher aggregate unemployment rates would lower the fraction of high quality workers in the labor force and generate hysteresis in aggregate unemployment rates.

In sim, the labor market segmentation appzoach is a promising avenue for the investigation of unemployment at both the mieroeconomic and macroeconomic jevels. 


\section{REFERENCES}

Blanchazd, Olivier J. and Diamond, Peter, "Ranicing. Unemployment Duration, and Wages," NBER Working Paper, 1990.

Bowles, Samuel, "The Production Process in a Competiclve Economy: Walrasian, Neo-Hobbeglan, and Marxlan Models, American Economic Review, 75 (March 1985): $16-36$.

Bulow, Jeremy I. and Summers, Lawrence H., "A Theory of Dual Labor Harkets with Application to Industrial Policy, Discrimination and Keynesian themployment," Journal of Labor Economics, July 1986, 376-414.

Carnoy, M. And Rumberger, R., "Segmentation in the U.S. Labor Market: Its Effects on the Mobility and Earnings of whites and Blacks, "Cambritge Journal of Economies, 4 (June 1980): 117-32.

Clark, Kin and Sumers, Lawrence H., "Labor Market Dynamies and Unemployment: A Recongideration," Brookines Papers gn Economic Activity, No. 1 (1979): 1360 .

Dickens, W1lliam $T$, and Katz, Lawrence $F$. , "Interindustry Wage Differences and Industry Characteristies," in Kevin Lang and Jonathan S. Leonard, eds., UnempIoyment and the Structure of Labor Markets. Oxford:Basil Blackwell, 1987.

Dickens, William $T$. and Katz, Lawrence $F$., "Interindustry Wage Differences and Theorles of Wage Determination," NBER Working Paper, 1987.

Dickens, William T. and Lang, Kevin, "A Tast of Dual Labor Market Theory," American Economic Reyiew, 75 (September 1985): 792-805.

Dickens, William T. End Lang, Kevin, "Why It Matters what We Trade: A Case for Active Policy," in Lsura D'Andrea.Tyson, William T. Dickens, and John Zysman, eds., The Dynamics of Trade and Employment, Cambrfdge, MA: Ballinger, 1988.

Dickens, William T, and Lang, Kevin "Labor Market Segmentation Theory:

Reconsidering the Evidence," in William Darity, Jr. ed, Controversies in Labor Economics, NY: Kiuwer, fortheoming, 1992.

Katz, Lawrence $F$, and Sumers, Lawrence H., "Industry Rents; Evidence and Implications," Brookings Papers on Economic Activity, (1989); $209-75$.

Krueger, Alan and Sumers, tawrence $k$, "Reflections on the Interindustry wage Structure," in. Kevin Lang and Jonathan S, Leonard, eds., Unemployment and the Structure of Labor Markets. Oxford:Bas1l Blackwe11, 1987.

Krueger, Alan and Sumers, Lawrence H., "Efftctency Wages and the InterIndustry Wage Structure," Econometrica, 56 (March 1988): 259-93.

Lang, Kevin, "Pers1stent Wage Dispersion and Involuntary Unemployment," Quarterly Journal of Economics, 106 (Feb. 1991): 181-202.

Montgomery, James D., "Equilibrium Wage Dispersion and Interindustzy Wage Differentials," Quarterly Journal of Economics, 106 (Feb, 1991): 163-180. 
Orr, Douglas V., "Segmented Labor Markets and Local Unemployment Rates." Eastern Washington University, unpublished, 1991.

Piore, Michael, J,. "Notes for a Theory of Labor Markec Segmentation," in Richard C. Edwards et al., eds., Labor Market Segmentation, Lexington, MA: D.C. Heath, 1975 .

Rebitzer, James and Taylor, Lowe1l, "A Model of Dual Labor Markets when Product Demand is Uncertain, " Quarterly Journel of Economies, forthcoming 1991.

Reich, Michael, Racial Inequality: A Polltical Economy Analysis, Princeton, NJ: Princeton Untversity Press, 1981.

Roemer, John, "Divide and Conquer: Microfoundations of a Marxian Theory of Hage Determination," gell Journal of Economics, 10 (Aurum 1979).

Stone, Kathrine, "The Origin of Job Structures in the Steel Industry," in Richard C. Edwards et al., eds., Labor Marker Segmentation, Lexington, MA: D.C. Heath, 1975.

Wial, Howard, "Getting A Good Job: A Case Study of Mability in a Segmented Labor Market," Industrial Relations, (forthconing), 1991. 
TABLE 1

Factor scores

\begin{tabular}{|c|c|c|}
\hline Industry & Factor 1 & Factor 2 \\
\hline $\begin{array}{l}\text { FOOD } \\
\text { BEVERAGES }\end{array}$ & $\begin{array}{l}0.56670 \\
0.29004\end{array}$ & $\begin{array}{r}-0.03886 \\
0.20975\end{array}$ \\
\hline TOBACCO & 0.24957 & 0.56074 \\
\hline TEXTILES & 1.00276 & -0.13598 \\
\hline APPAREI & 1.94317 & -0.25218 \\
\hline LEATHER & 1.29356 & -0.24779 \\
\hline FOOTWEAR & 1,46189 & -0.28176 \\
\hline WOOD PROD & 0.92414 & $-0.25 \pm 31$ \\
\hline FURNITURES & 1,00104 & -0.34971 \\
\hline PAPER & -0.50041 & 0.00016 \\
\hline PRINT/PUBL & $-0,64398$ & 0.03131 \\
\hline IND CHEM & -0.56831 & 0.70669 \\
\hline OTHER CHEM & -0.26609 & 0.75676 \\
\hline REF PETROL & -1.61949 & 3.97735 \\
\hline COAL/PET PR & $-0,97309$ & 1.62394 \\
\hline RUBBER PROD & -0.37961 & -0.24478 \\
\hline FLAST PROD & 0.35907 & 0.08102 \\
\hline POTTERY/CHINA & 0.23095 & -0.06389 \\
\hline GLASS PROD & -0.01511 & 0.21659 \\
\hline OTHER NIN PR & $-0,11155$ & 0.08483 \\
\hline IRON/STEEL & -1.36486 & -0.59199 \\
\hline N.FERROUS MET & -1.01851 & -0.64635 \\
\hline FABR METALS & 0.17669 & -0.01273 \\
\hline MACHINERY & -0.21395 & -0.15863 \\
\hline ELECT MACH & 0.03046 & 0.18566 \\
\hline TRANSP EQUIP & -0.55172 & -0.01614 \\
\hline SCIENTIF EQ & 0.34500 & -0.01370 \\
\hline OTHER MANUF & 0.71 .655 & -0.52841 \\
\hline MINING & -3.02770 & -3.11332 \\
\hline CONSTRUCTION & -0.23518 & $=0.39395$ \\
\hline TRANSP/COMM & -0.68521 & -0.65663 \\
\hline AGRICULTURE & 1.58416 & -0.43664 \\
\hline
\end{tabular}

